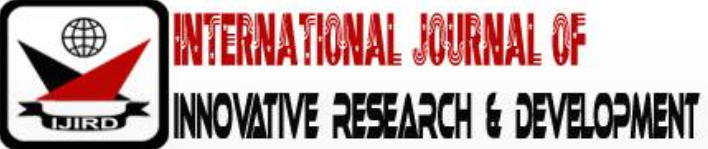

ISSN 2278 - 0211 (Online)

\section{Domestic Debt Burden and Economic Growth in Nigeria (1981 - 2014)}

\begin{tabular}{|c|}
\hline Dr. Olushola Babatunde Oluwalaiye \\
Senior Lecturer, Department of Economics, \\
Babcock University, Ilishan Remo, Ogun State, Nigeria \\
Dr. Abolade Francis Akintola \\
Senior Lecturer, Department of Finance, \\
Babcock University, Ilishan Remo, Ogun State, Nigeria \\
Oluwafunmilayo Adenike Olaleye \\
M.Sc Student, Department of Finance, \\
Babcock University, Ilishan Remo, Ogun State, Nigeria
\end{tabular}

\begin{abstract}
:
The paper investigates domestic debt burden and economic growth in Nigeria from 1981 to 2014. Ex-post facto research design was adopted in this study with data obtained from Central Bank of Nigeria statistical Bulletin, publication from National Bureau of Statistics and annual report from Debt Management Office. Regression analysis of ordinary least square (OLS) was used to analyse secondary data obtained. The results of ADF, Co-integration and Johansen Juselius showed that domestic debt contributes to growth rate of Gross Domestic Product (GDP). The study therefore recommends that domestic debt should be well managed and spends on long-term developmental project that would impact positively on the welfare of the citizens.
\end{abstract}

Keywords: Domestic debt, debt financing, welfare indicator, human capital and capital formation

\section{Introduction}

According to Oyejide, Soyode and Kayode (1985), debt is defined as the resource or money in use in an organization which is not contributed by its owner and does not in any other way belong to them. It is a liability represented by a financial instrument or other formal equivalent. Debt is an essential tool for financing public infrastructure. Many scholars have supported the fact that increase in government expenditure or human capital development and physical infrastructures is strategic to the socio-economic development of a nation, it includes education, health, labour, employment and women affairs. Also, expenditure on infrastructure such as roads, communications, power, and so on, reduces production costs, increases private sector investment and profitability of firms, as well as investing in human capital development targeted at ensuring that the nation's human resource endowment is knowledgeable, skilled, productive and healthy to enable the optimal exploitation and utilization of other resources, thus fostering economic growth (Ogujiuba, 2013).

In the literature, many authors such as Gunakar (2013), Adofu and Abula (2010), argued over time about the national debt presence and its threats for the country's economic development. According to Keynesian economists, governments should increase the national debt to stimulate the economy during downturns and retire the debt during business cycle upturns. Debt could be paid by raising taxes. Government could also reduce debt through other options such as reducing spending or issuing more money.

Adofu and Abula (2010) stated that in Nigeria, several factors have been advanced to explain the changing domestic debt profile from 1960s to date. The major factors include - high budget deficits, low output growth, large expenditure growth, high inflation rate and narrow revenue base witnessed since the 1980s. Output growth declined as it recorded annual average value of $5 \%$ in $1980-1984,4 \%$ in $1990-1994$ and $2.8 \%$ in 1998 - 1999 period respectively. However, growth was recorded in 2003 (Ajayi \& Oke, 2012). It is usually expected that as countries expand their output, they also tend to rely more heavily on domestic public debt issuance to finance growth. The constraining effect of the debt burden becomes more pronounced as the existing infrastructure does not match the volume of debt burden. Amasssoma (2011) asserted that a misuse of resource may easily lead to a build - up of debt to unsustainable levels which has been a major impediment to growth in emerging economies including Nigeria. According to Adofu and Abula (2010), Nigeria has been alone in experiencing escalating levels of government domestic indebtedness, but in comparison to other countries in Sub-Sahara Africa, Nigeria's domestic debt to (GDP) ratio is clearly on the high side. This may have had adverse effects on the growth of Nigeria Economy, due to the high rate of servicing the debt. Thereis thus a strong cross-country relationship 
between economic growth and the total size of the debt market. It is for all the reasons above; this study investigates domestic debt burden and economic growth in Nigeria from 1981 to 2014.

\section{Literature Review}

This section focussed on the review of studies carried out in the areas related to this study. The review follows conceptual, theoretical and empirical literature making references to the contributions and findings of past researchers.

\subsection{Conceptual Review}

\subsubsection{Concept of Domestic Debt}

Domestic debt is defined as debt denominated in Local Currency. Central Bank of Nigeria (CBN) administers domestic debt through the issuance of:

- $\quad$ Nigeria Treasury Bills

- Nigeria Treasury Certificates

- Federal Government Development stock

- Treasury Bond

- Ways and Means advances

\subsubsection{Concept of Treasury Bill}

Treasury bills are discountable instruments used by the central bank of Nigeria (CBN) to manage liquidity in the system, usually on short-term basis. The tenors are short with maximum of 364 days with yields far higher in comparison to what the money market offers. The Debt Management Office (DMO) commenced the smothering and restructuring of the treasury bills in 2004. The restructuring entailed extending the maturities of the existing treasury bills by issuing tenors of 6, 12, 24 and 36 months.

\subsubsection{Concept of Treasury Certificate}

Treasury Certificate which were first issued in 1968 constituted one of the largest securities between 1983 and 1988. In 1995, the federal government of Nigeria (FGN) decided to further reduce the debt service obligation on domestic debt. A treasury bill certificate was therefore abolished in 1996.

\subsubsection{Concept of Treasury Bond}

FGN Bonds are debt securities (Liabilities) of the federal government of Nigeria issued under the authority of Debt Management Office (DMO) and listed on the Nigerian stock exchange. The FGN has an obligation to pay the bondholders the principal and agreed interest as they fall due. To buy bonds means lending to federal government for a specified period of time. The FGN bond is considered as the safest of all investments in domestic currency securities market because it is backed by the 'full faith and credit' of the government. They have no default risk, meaning that the interest and principal will be paid as at when due.

\subsubsection{Concept of Development Stock}

Development stocks were apparently the first government instruments to be issued. It is floated largely to provide development finance either directly to meet the needs of the federal government or as loan on lent to the state government. The development stocks were first registered debt stocks 1956/61. The stock outstanding increased between 1960, 1987 and 1988. Development stock is traded in the secondary market of the Nigeria Stock Exchange (NSE).

\subsubsection{Concept of External Debt}

External debt burden is the reflection of the difficulties and strains arising from the servicing of external debt. This may result from inability to generate enough resources to meet commitments in debt servicing. The burden is measured in term of the proportion of current resources (income) devoted to financing fast consumption. Ajayi and Oke (2012) investigated the effect of external debt on economic growth and development in Nigeria employing ordinary least square method of data analysis and found that external debt burden had an adverse effect on the national income and per capital income of the nation, and high level of external debt led to devaluation of the nation currency, increase in refreshment of workers, continuous industrial strike and poverty.

\subsubsection{Concept of Economic Growth}

Traditionally, many economists and other professional failed to make clear distinction between the concept of economic growth and economic development, thereby generating debate in literature. Some scholars considered economic development as a process that generate economic and social, quantitative and particularly,qualitative changes, which causes the economy to cumulatively and durably increase its real nominal product. In contrast and compared to development, economic growth is therefore, a narrower concept then economic development, because the former is in a limited sense, is an increase of the national income per capita, and involves the analysis, especially in quantitative terms of this process, the functional relations between the endogenous variables. In a wider sense, it involves the increase of Gross Domestic Product (GDP),Gross National Product (GNP) and National Income (NI), including the production capacity expressed both in absolute and relative size, per capital, encompassing also the functional modifications of the economy. 
Economic growth could therefore be seen as the process of measuring the size of national economics, the macro-economic indications, especially the GDP per capital, in an ascendant but not necessarily linear direction, with positive effects on the economic - social sector, while development shows how growth impacts on the society by increasing the standard of life (Oshadami, 2006).

\subsection{Theoretical Framework}

\subsubsection{Theory of Balanced Growth}

According to Lewis (1955), the theory of balanced growth states that there should be a simultaneous and harmonious development of different sectors of the economy so that all sectors grow together. However, for this to be achieved, a balance is required between the demand and supply sides. The supply side has to do with the simultaneous development of all inter-related sectors which help in increasing the supply of goods which comprises of issues such as investment in power, agriculture, irrigation transport while the demand side concerns the provision of employment opportunities and increasing incomes so that the demand for goods and services may rise on the part of the consumers. The balanced growth theory has a similar focus with Solow's model of long run growth but it is instructive to say that they cannot be simply substituted for each other.

\subsubsection{The Endogenous Growth Model}

This theory holds that economic growth is primarily the result of endogenous and not external forces. Endogenous growth theory further states that investment in human capital, innovation, and knowledge are significant contributors to economic growth. The theory also focuses on positive externalities and spill over effects of a knowledge-based economy which will lead to economic development. Lucas (1988) assumes that investment on education leads to the production of human capital which is the crucial determinant in the growth process. He makes a distinction between the internal effects of human capital where the individual worker undergoing training becomes more productive, and external effects which spill over and increase the productivity of capital and of other workers in the economy. It is investment in human capital rather than physical capital that have spill over effects that increase the level of technology. Thus, the output for firmi take the form:

$\mathrm{Yi}=\mathrm{A}(\mathrm{Ki}) \cdot(\mathrm{Hi}) \mathrm{H}^{\mathrm{e}}$

Where A is the technical co efficient, Ki and Hi are inputs and human capital used by the firm to produce goods Yithe variable $\mathrm{H}^{\mathrm{e}}$ is the economy's average level of human capital. The parameter ' $\mathrm{e}$ ' represents the strength of the external effects from human capital to each firm's productivity.

\subsubsection{Theory of Debt Burden Shifting}

The theory of debt burden shifting states that a present tax -cut by debt finance is actually a shifting of burden from present to future tax - payers. Therefore, a present rise in the level of public debt simply means an increase in taxation in future to retire the debt and interest thereon indicating the burden of debt in terms of future taxes. The question that who actually bears the burden of debt in future has remained long debate since David Ricardo's proposition about the equivalence of debt and taxes.

\subsubsection{Theory of Welfare}

This version of welfare theory was discussed in Wealth and Welfare by Pigou (1912). The term "Welfare' is generally referred to as 'Happiness' or 'prosperity' which is achieved through the availability of desirable resources appropriate to make the living condition comfortable. Welfare economics analysis the total good or welfare that is achieved at a current state as well as how it is distributed. This relates to the study of income distribution and how it affects the common goods. Because different "Optimal' state may exist in an economy in terms of the allocation of resources, welfare economics seeks the state that will create the highest overall level of social welfare. The role of government is important in this context as it extends a numbers of economic assistance to its citizens in terms of social insurance provision for unemployment, injured, or aged people or destitute or handicapped. Welfare programs are funded by that payers and allow people to cope with financial stress during rough periods of their lives.

\subsubsection{The Theory of Public Sector Budget: An economic perspective}

Budget theory development, particularly incrementalism, has focussed on explaining budget discussion rather than focusing on how budget policy and budget content is determined. An inherent assumption of incremental budget theory is that marginal budget decisions are the 'necessary tools for policy change negotiation' as marginal changes are more politically feasible. Therefore, incrementalism has greater value for explaining marginal budget or policy trade-offs than as a theory that explains what is in public budgets or what goods or services should be provided by the public versus the private sector. Thus, budget is a reflection of and the means by which the basic goals of government and society are achieved. The budgetary process is complicated by the fact that we often try to achieve separate policy goals through the use of one policy instrument.

\subsubsection{Theory of Crowding - Out}

Crowding out generally refers to the economic effects of expansionary fiscal action. If an increase finance by government demands either taxes or debt issuance to the public fails to stimulate total economic activity, the private 
sector is said to have been 'crowded out' by the government action. The presumption of a constant money supply insures that the policy action accompanying the increase in government demand is fiscal and not monetary.

The analysis may be conducted in either real or nominal terms. The crowding - out hypothesis maintains that if prices are held constant as in typicalIS-LM fashion, an increase in real government demand financed by real taxes or debt has no lasting effect on real income. Alternatively, crowding out implies that an increase in government spending, given flexible prices and a constant money supply, has no lasting effect on nominal income. In other words, the steady state government spending multipliers, under the above conditions, is approximately zero.

\subsubsection{Political Economy Theory of Public Debt}

The sustainability issues are a part of the positive approach to determining the causes of public debt. The main advocate of the normative approach to public debt is Robert Barro (1979), and Lucas and Stockey are close to him in their ways of thinking. Barro and his follower observed the state as a "benevolent social planner' whose aim is to maximize the welfare of members of the society. They believe that the effect of fiscal policy (that is taxation) are least distorted if tax rates are constantly kept on the same level. Since economies pass through periods of expansion and periods of recession, with constant tax rates they will undergo alternate periods of budget deficit and budget surplus. Also, the appearance of deficit or surplus will depend on the effect that some external factors have on public expenditures. Thus, debt will be used in periods of temporary increase in public expenditure (especially in periods of war and big crises) while in post - war (post -crisis) periods, unchanged rates will generate budget surplus which will compensate for the present deficit in terms of its current value (Heinemann, 1992). In other words, the idea of this approach is that tax rates 'smoothed out the time' will have the most neutral effect on the economy. This is why this approach is sometimes called 'equilibrium on approach to fiscal policy' or 'tax smoothing policy'. The appearance of public debt is only a logical result of pursuing such a policy in the periods when it is justified.

\subsection{Empirical Review}

Adofu and Abula (2010), investigated the effect of rising domestic debt on the Nigeria economy (1986 -2005), using descriptive and analytical approach to determine the effects of variables such as domestic debt, domestic credit and interest rate or gross domestic product as a measure of growth. The result of their analysis shows that the regression coefficient of domestic debt in the estimated regression is -0.428 which implied that 42.8 decrease in gross domestic product within the period covered. Also, they found that the rise in domestic debt profile in Nigeria is attributed to government extra budgetary activities, which most often are not used to the intended project. Tshiswaka - Kashalala (2006) analysing the sustainability of the government of south Africa's fiscal policies during the period 1990-2005 using quarterly data, found that government revenue, government spending on goods and services, and interest payment are non-stationery but co-integrated. A standard three variable frame work of vector error correlation (VEC) model was used by the author to test whether data from the historical process in south Africa are consistent with the intertemporal government budget constraint.

Abbas and Christensen (2007) examined the role of domestic markets in economic growth; an empirical investigation for low - income countries and emerging markets using panel econometric techniques to examine the endogeneity of domestic debt and its impact on growth with a view to obtaining a sense of the optimal size and quality of domestic debt. They found the following, among others; higher private savings increase the scope for domestic debt issuance while a larger supply of domestic debt instruments provide incentives to increase private savings. But financial depth had a surprisingly weak causal contribution to income and the growth contribution of domestic debt is higher if it is marketable, bears positive real interest rates and is held outside the banking system.

Siddiqui and Malik (2002) estimated directly the impact of debt on GDP growth rate and argued that debt accumulation and growth had a non-linear relationship; up to a certain level the impact was positive and beyond the threshold level the relationship turned negative. The study exerted mixed evidence regarding the impact of debt burden on economic growth. While debt accumulation in other countries of south Asia so far has not had a negative impact on the growth rate, debt accumulation in the case of Pakistan in resulting in low growth.

Shilkh, Faridi and Tariq (2010) investigated impact of domestic debt on economic growth in Pakistan by applying the OLS technique for the period 1972 to 2009. The study indicated that the stock of domestic debt affects the economic growth positively in Pakistan. They concluded that the resources generated through domestic borrowing have been used partially to finance those expenditures of government which contribute to the economic growth. Moreover, they found that there is a negative relationship between domestic debt servicing and economic growth. They suggested that the result is due to the fact that huge burden of non-development expenditures harms the economic growth. The finding of the study revealed that the negative impact of domestic - debt

Servicing on economic growth is stronger than positive impact of domestic debt on economic growth.

Yasin (2000) in trying to find a conclusive position examined the effect of government spending on economic growth using panel data set from Sub-Saharan Africa. The results he got by employing a fixed and random estimation techniques indicated that government spending on infrastructure had positive and significant effect on economic growth. By nurturing productive activities, reducing unproductive ones and implementing appropriate policies, the relationship between government spending and economic growth can be maintained in the positive direction.

\section{Methodology}

Ex-post facto research design was adopted in this study. Annual time series data were collected from secondary source from 1981 to 2014. The data were collected principally from Central Bank of Nigeria (CBN) statistical bulletin, 
publication from National Bureau of Statistics (NBS) and annual report of Debt Management Office (DMO). Regression analysis of the ordinary least square (OLS) is the estimation technique that was employed in this study with the aid of statistical software- econometric view to determine the impact of domestic debt burden on economic growth in Nigeria. To achieve robust statistical analysis and better result, the econometric model was formulated through the use of regression analysis to obtain the relationship between the dependents and explanatory variables. The model to capture domestic debt burden on economic growth in Nigeria is stated below;

Based on assumption of linearity of the variables, we take natural log of both sides, then the model becomes:

LNRGDP $_{t}=\beta_{0}+\beta_{1}$ LNDDO $_{t}+\beta_{2}$ LNCF $_{t}+\beta_{3} L_{\text {NHC }}+\mu_{t}$

Where: GDP $=$ Real Gross Domestic Product

DDO = Domestic Debt Outstanding

$\mathrm{CF}=$ Capital Formation

$\mathrm{HC}=$ Human Capital

$\mu=$ Stochastic Error Term

The parameters of the models were estimated using the ordinary least square (OLS) techniques. The unit root tests and techniques of co-integration were adopted to help overcome problem of spurious regression results that might arise from the use of standard OLS regression. Stability and diagnostic checks were put in place to check the stability of the model, and to further validate results obtained. The error correction model (ECM) was adopted in this study to capture the short run and long run dynamics.

\section{Data Analysis and Discussion of Findings}

In order to check for the descriptive properties of series and Skewness of the distributive function of data series, the summary statistics is presented in the table below:

\begin{tabular}{|c|c|c|c|c|}
\hline & LNRGDP & LNHC & LNDDO & LNCF \\
\hline Mean & 6.024254 & 12.80343 & 5.886944 & 5.276406 \\
\hline Median & 5.934365 & 12.75332 & 6.218202 & 5.445443 \\
\hline Maximum & 6.896087 & 14.34680 & 8.975124 & 8.343125 \\
\hline Minimum & 5.417877 & 10.96374 & 2.104134 & 2.174752 \\
\hline Std. Dev. & 0.447444 & 0.983170 & 2.075835 & 2.101276 \\
\hline Skewness & 0.452644 & 0.052276 & -0.263758 & 0.031523 \\
\hline Kurtosis & 2.069977 & 1.913331 & 1.824543 & 1.636867 \\
\hline Jarque-Bera & 2.456546 & 1.738012 & 2.420793 & 2.715572 \\
\hline Probability & 0.292798 & 0.419368 & 0.298079 & 0.257230 \\
\hline Sum & 210.8489 & 448.1200 & 206.0430 & 184.6742 \\
\hline Sum Sq. Dev. & 6.807008 & 32.86516 & 146.5091 & 150.1223 \\
\hline Observation & 35 & 35 & 35 & 35 \\
\hline
\end{tabular}

Table 1: Summary of Descriptive Statistic

Source: Researcher's Computation, (2020)

Note: LNRGDP - Real Gross Domestic Product

LNHC - Human Capital, Lnddo - Domestic Debt Outstanding, LNCF - Capital Formation

\subsection{Interpretation of Descriptive Statistics}

Real Gross Domestic Product (RGDP) Mean: It measures the average value of the series. It gives an average of 6.024254, which fluctuates for a minimum of 5.417877 and a maximum of 6.896087 . However, the median remained at 5.934365. the dispersion around the median indicated by the low value of standard deviation seen to be given as 0.447444. The Skewness around its mean gives a positive value of 0.452644 and appears to fall within boundary which means the distribution has long right tail. For kurtosis value that gives 2.069977 the distribution is flat and falls below threshold (3) which implied that RGDP is platykurtic relative to the normal.

Domestic Debt Outstanding (DDO): The mean gives an average of 5.886944, which fluctuates for as minimum of 2.104134 and maximum of 8.975124. However, the median remained at 6.218202. The dispersion around the median indicated by the high value of standard deviation seen to be given as 2.075835. The Skweness around its mean gives a negative value of -0.263758 and appears to fall within boundary which means the distribution has long right tail. For kurtosis value that gives 1.824543 the distribution is flat and falls below threshold (3) which implied that DDO is platykurtic relative to the normal.

Capital Formation (CF) Mean: it gives an average of 5.276406, within a minimum of 2.174752 and a maximum of 8.343125. However, the media remained at 5.445443. The dispersion around the median indicated by the high value of standard deviation seen to be given as 2.101276. The Skweness around its mean gives a positive value of 0.031523 and appears to fall within boundary which means the distribution has long right tail. For kurtosis value that gives 1.636867 the distribution is flat and falls below threshold (3) which implied that CF is platykurtic relative to the normal

Human Capital (HC): it record of mean is 12.80343, which is the highest in the series it fluctuates for a minimum of 10.96374 and a maximum of 14.34680 . However, the median remained at 12.75332 . The dispersion around the median indicated by the high value of standard deviation seen to be given as 0.983170 . The Skweness around its mean gives a positive value of 0.052276 and appear to fall within boundary which means the distribution has long right tail. For 
kurtosis value that gives 1.913331 the distribution is flat and falls below threshold (3) which implied that CF is platykurtic relative to the normal.

However, the Table shows that all the variables are normally distributed since all the probabilities are less than the Jacque Bera (chi-square) distribution at the $5 \%$ level of significance.

\subsection{Results of the Empirical Analysis}

The empirical analysis covers unit root test, and co-integration, the results and discussion presented below:

\subsubsection{Unit Roots Tests Results}

Variable in the models were subjected to a stationarity test as part of the necessary diagnostic check and precondition to run the vector error correction model to avoid spurious regression result. It is only when macroeconomic variable are either stationary or corrected and make stationary that they are suitable for economic analysis, forecasting and making policy decisions. This test was carried out in line the procedure of Augmented Dickey and Fuller (1981).

The unit root tests results confirms that most economic variables exhibit trends of non-stationarity in their level forms. However, the first or second differenced terms of most variable will usually be stationary.

The rejection of null hypothesis root is hinged on the result of the ADF statistics, critical values and p-values. If pvalue is significant i.e. less than 0.05 , we cannot accept the null hypothesis, but rather reject null and accept alternate hypothesis. Also, if the ADF statistic is less than the critical value (absolute). We reject the null and accept the alternate hypothesis.

\begin{tabular}{|c|c|c|c|c|}
\hline Variable & $\begin{array}{c}\mathbf{5 \%} \text { Critical } \\
\text { Values }\end{array}$ & Level & $\mathbf{1}^{\text {st }}$ Difference & $\begin{array}{c}\text { Order of } \\
\text { Integration }\end{array}$ \\
\hline LNRGDP & -2.954021 & 3.396095 & -4.520932 & $\mathrm{I}(1)$ \\
\hline LNDDO & -2.954021 & -1.630205 & -4.715103 & $\mathrm{I}(1)$ \\
\hline LNCF & -2.960411 & -1.312613 & -2.221569 & $\mathrm{I}(1)$ \\
\hline LNHC & -3.548490 & -0.485097 & -6.229849 & $\mathrm{I}(1)$ \\
\hline
\end{tabular}

Table 2 : Result of the ADF Unit Root Test

Source: Researcher computation

\begin{tabular}{|c|c|c|c|c|}
\hline Variable & $\mathbf{5 \%}$ Critical Values & Level & 1st Difference & Order of Integration \\
\hline LNRGDP & -1.98000 & 1.78856 & -2.51491 & $\mathrm{I}(1)$ \\
\hline LNDDO & -1.98000 & -0.02326 & -2.77327 & $\mathrm{I}(1)$ \\
\hline LNCF & -1.98000 & -3.17193 & -1.33791 & $\mathrm{I}(1)$ \\
\hline LNHC & -1.98000 & -2.61312 & -2.75379 & $\mathrm{I}(1)$ \\
\hline
\end{tabular}

Table 3 : Results of the Ng-Perron Unit Root Test

Source: Researcher computation

The results of the unit root tests concluded using the ADF statistics and the Ng-perron statistic shown above reveals that the variables: Real gross domestic product, domestic debt outstanding, capital formation, human capital, welfare indicator, and debt financing were made stationary at their first difference. With their P-value all below 5\% significance level. So from the results, real gross domestic product is an I (1) variable, domestic debt outstanding is an I (1) variable, capital formation is an I (1) variable, human capital is an I (1) variable, welfare indicator is an I (1) variable, while debt financing is also an I(1) variable. The results been supported by the Ng-Perron results, with LNRGDP value -2.51491, LNDDO value -2.77327 , LNHC value -2.75379 and LNCF -1.33791 . The variable was made stationary at their first test of difference.

\subsubsection{Co - integration Test Analysis}

The lag length selection test was conducted to ascertain the optimal lag length required form the Co-integration test as well as the Error Correction Model, this is because the coefficient of a variable at time t-1 (past) could affect or reinforce the coefficient of same variable at time $t$ (present). The Schwarz Information Criterion was adopted, and it indicates lag order one (1) for the optimal lag length.

The lag length result is presented below;

Endogenous variables: LNRGDP LNHC LNCF LNDDO

Endogenous variables: $\mathrm{C}$

\begin{tabular}{|c|c|c|c|c|c|c|}
\hline Lag & LogL & LR & FPE & AIC & SC & HQ \\
\hline 0 & -23.60674 & NA & $6.26 \mathrm{e}-05$ & 1.673136 & 1.854531 & 1.734170 \\
\hline 1 & & & & - & - & - \\
& 131.8074 & $263.7331^{*}$ & $1.35 \mathrm{e}-08^{*}$ & $6.776260^{*}$ & $5.869232^{*}$ & $6.471037^{*}$ \\
\hline 2 & 147.0901 & 22.22941 & $1.48 \mathrm{e}-08$ & -6.732735 & -5.100181 & -6.183430 \\
\hline
\end{tabular}

Table 4: Lag Length Result

*Indicates Lag Order Selected by the Criterion

Source: Researcher computation 
The lag length selection indicates optimal lag at once, which makes the variables in the model LNRGDP, LNHC, LNCF, and LNDDO suitable for the co-integration test.

\subsubsection{Johansen Juselius Tests Results}

Since all variables have the same order of integration that is I (1), and the Shwatrz information criterion has indicated a lag order of one (1), the next step is to determine if the variables are co-integrated. To do this, JohansenJuselius maximum likelihood method of co-integration was employed. If the model is co-integrated, then Error Correction Model (VECM), will be used but if not, the unrestricted model will be used. The implication of the variables if found cointegrated means that they all share common stochastic trend and will grow proportionally, in order words, a long run relationship exist among them.

\begin{tabular}{|l|l|l|l|l|l|l|}
\hline \multicolumn{7}{|c|}{ Unrestricted Cointegration Rank Test (Trace) } \\
\hline $\begin{array}{c}\text { Hypothesized } \\
\text { Number of } \\
\begin{array}{c}\text { Cointegrating } \\
\text { Equation (r) }\end{array}\end{array}$ & Eigenvalue & $\begin{array}{c}\text { Trace } \\
\text { Statistics }\end{array}$ & $\begin{array}{c}\mathbf{0 . 0 5} \\
\text { Critical } \\
\text { Value }\end{array}$ & Prob.** & Remark & Decision \\
\hline $\mathrm{r} \leq 0^{*}$ & 0.637890 & 50.90469 & 47.85613 & 0.0251 & Significant & Reject H0 \\
\hline $\mathrm{r} \leq 1$ & 0.338606 & 17.38302 & 29.79707 & 0.6117 & Insignificant & AcceptNH0 \\
\hline $\mathrm{r} \leq 2$ & 0.104173 & 3.740631 & 14.49471 & 0.9233 & Insignificant & Accept H0 \\
\hline $\mathrm{r} \leq 3$ & 0.003339 & 0.110366 & 3.841466 & 0.73397 & Insignificant & Accept H0 \\
\hline
\end{tabular}

Table 5: Johansen-Juselius Co-Integration Result for Model 1

Trace Test Indicates 1 Cointegrating $\operatorname{Eqn}(S)$ at the 0.05 Level

Source: Researcher Computation

Having tested the stationarity of each time series, the next step is to test for co integration between the variables. The Johansen procedure is used to identify long run relationship among the variables. Co integration of the dependent variable with the independent variable forms a dynamic basis through which forecast can be made. The table below shows that the dependent variable RGDP is cointegrated with the independent variables. The trace statistics is greater than the critical values at $5 \%$ level of significance for at least 1 equation; this indicates a rejection of the null hypothesis of no cointegration in favour of three cointegration relationships between the variables. The result further explains that there is long run relationship between the variables.

\begin{tabular}{|l|l|l|l|l|l|l|}
\hline \multicolumn{7}{|c|}{ Unrestricted Cointegration Rank Test (Maximum Eigenvalue) } \\
\hline $\begin{array}{c}\text { Hypothesized } \\
\text { Number of } \\
\begin{array}{c}\text { Cointegrating } \\
\text { Equation (r) }\end{array}\end{array}$ & Eigenvalue & $\begin{array}{c}\text { Trace } \\
\text { Statistics }\end{array}$ & $\begin{array}{c}\mathbf{0 . 0 5} \\
\text { Critical } \\
\text { Value }\end{array}$ & Prob.** & Remark & Decision \\
\hline $\mathrm{r} \leq 0^{*}$ & 0.637890 & 33.52167 & 27.58434 & 0.0077 & Significant & Reject H0 \\
\hline $\mathrm{r} \leq 1$ & 0.338606 & 13.64239 & 21.13162 & 0.3951 & Insignificant & Accept H0 \\
\hline $\mathrm{r} \leq 2$ & 0.104173 & 3.630266 & 14.26460 & 0.8962 & Insignificant & Accept H0 \\
\hline $\mathrm{r} \leq 3$ & 0.003339 & 0.110366 & 3.841466 & 0.7397 & Insignificant & Accept H0 \\
\hline
\end{tabular}

Table 6: Maximum Eigenvalue

Max-Eigenvalue Test Indicates 1 Cointegrating Eqn(S) at the 0.05 Level

*Denotes Rejection of the Hypotheses at the 0.05 Level

**Mackinnon-Haug-Michelis (1999)

The Maximum Eigenvalue indicates one (1) cointegrating equation at the 0.05 level of significance, also shows a co-integrating value in at least one variable with its probability at 0.0077 , trace statistics at 33.52167 as against the critical value 27.58434 which led to the rejection of null hypothesis that domestic debt has not contributed to economic growth in Nigeria and the alternative accepted.

\section{Conclusion}

The main objective of the study is to evaluate the contribution of domestic borrowing on economic growth and welfare of the citizens in the period 1980 to 2014 in order to make recommendations on how to mitigate the risks of domestic debt in Nigeria.

The study found that with log magnitude of our coefficient, it obviously implies that the funds generated through domestic borrowing have been used partially to finance those expenditure of government which contribute to growth rate of GDP. The principle is that domestic debt should be well managed and be spent on long-term developmental projects that would impact positively on the welfare of the citizen.

\subsection{Recommendations}

In line with the findings of the study, the following recommendations are hereby made; 
- Government should maintain a proper balance between short term and long term debt instruments in such a way that long term instruments dominate the debt market. Even if the ratio of the long term debt is a multiple of deposit, the economy can still accommodate it so long as the proceeds is channelled towards improving physical and human capital accumulation as well as Nigerians socio-economic welfare.

- Government should make efforts to settle the outstanding domestic debt. This will give room for proper conduct of monetary policy in the economy.

- Also government should strive to finance her budget deficit by improving on the present revenue base rather than resorting to domestic borrowing. This can be achieved by improving its revenue sources.

\section{References}

i. Abbas, S. \& Christensen, J. (2007) The role of domestic debt market in economic growth: An empirical investigation for low income countries and emerging market. IMF working paper.

ii. Adofu, I \& Abula, M. (2010) Domestic debt and the Nigerian economy. Current Research Journal of Economic Theory 2(1), 22-26

iii. Ajayi, L.B., \& Oke, M.O. (2012) Effect and development in Nigeria. International Journal of Business and Social Science.

iv. Amassoma, D. (2011). External debt, internal debt and economic growth bound in Nigeria using a causality approach. Current Research Journal of Social Sciences. 3(4), 320-325.

v. Barro, R. (1979) on the determination of public debt. Journal of Political Economy Vol 87, 940-971.

vi. Gunakar, B. (2013). An assessment of the impact of external debt on economic growth of Nepal.

vii. Lewis, W.A (1954). Economic development with unlimited supplies of Labour. Manchester School 22 (May, 1994) 139-191

viii. Lucas, R.E (1988) On the mechanics of economic development. Journal of monetary economics 22(1), 3-42

ix. Ogujiuba, K. (2013). The impact of human capital formation on economic growth in Nigeria. Journal of Economics, $4(2)$.

x. Oshadami, O.L (2006). The impact of domestic debt on Nigeria's economic growth. Unpublished B.sc project.

xi. Oyejide, T., Soyede, A. \& Kayode, M.O. (1985) Nigeria and the IMF. Ibadan, Heinemann Educational Books Nigeria Limited.

xii. $\quad$ Pigou, A.C. (1920). The economics of welfare. London Macmillan.

xiii. Sheikh, M.R., Faridi, M.Z., \& Tariq, K. (2010) Domestic debt and economic growth in Pakistan: An empirical analysis. Pakistan Journal of Social Sciences (PJSS) 30(2).

xiv. Siddiqui, R \& Malik, A. (2002) Debt and economic growth in South Asia. The Pakistan Development Review 4(4).

Xv. Solow, R.M. (1994) perspective on growth theory. The Journal of Economic Perspective 8(1) 45-54

xvi. Tshiswaka-Kashalala, G. (2006). Is fiscal policy sustainable in South Africa? An application of the Economic Approach.

xvii. Yasin, M. (2000). Public spending and economic growth: Empirical investigation of sub-Saharan Africa. SouthWestern Economic Review 1(10). 